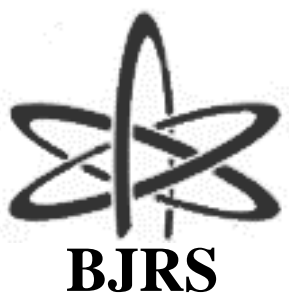

\author{
BRAZILIAN JOURNAL \\ $\mathrm{OF}$ \\ RADIATION SCIENCES \\ 07-2A (2019) 01-11
}

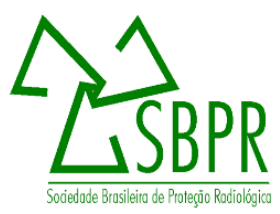

\title{
Elementary characterization of Ti metal alloys used in implant dentistry
}

\author{
C. A. M. P. Torres ${ }^{\text {a }}$; S. A. Paschuk ${ }^{\text {a }}$, A. S. S. Rocha ${ }^{\text {a. }}$ V. Deniak ${ }^{\text {b }}$ J.N. Corrêa ${ }^{\text {a }}$ L. \\ Camargo ${ }^{\text {c. J. T. Assis }}{ }^{\mathrm{d}}$ \\ ${ }^{a}$ Federal University of Technology - Paraná, UTFPR/DAFIS , 80230-90, Av. Sete de Setembro, 3165 \\ Curitiba, PR - Brazil \\ ${ }^{\mathrm{b}}$ Biotechnology applied to the health of children and adolescents /Pelé Pequeno Principe Research Institute, 80250- \\ 060, Av. Silva Jardim, 1632 - Curitiba - PR - Brazil \\ c Paranaense University/ 87502-210, Pç.Mascarenhas de Moraes, 4282, Umuarama-PR-Brazil \\ ${ }^{d}$ Polytechnic Institute of Rio de Janeiro (IPRJ)/State University of Rio de Janeiro - UERJ, 20550-900, St. São Fran- \\ cisco Xavier, 524, Maracanã, Rio de Janeiro, RJ, Brazil \\ cata-montenegro@bol.com.br,spaschuk@gmail.com
}

\begin{abstract}
The main goal of present work is analytical characterization of standard dental implants broadly used by Brazilian dentists. An ideal biological alloy for dental implants must have very high biocompatibility, which means that such material should not provoke any serious adverse tissue response. Dental implants are generally marketed as commercially pure titanium (TiCP) due to their excellent mechanical and physical properties. However, sometimes other alloys are employed and consequently it is essential to study the chemical elements present in those alloys that could bring prejudice for the health. Present work investigated TiCP metal alloys used for dental implant manufacturing and evaluated the presence of elements. For alloy characterization and identification of elements it was used EDXRF technique. This method allows to perform the qualitative and quantitative analysis of the materials using the spectra of the characteristic $\mathrm{X}$-rays emitted by the elements present in the metal samples. The experimental setup was based on two X- ray tubes, Mini X model with Ag and Au targets and X-123SDD detector (AMPTEK) and a $0.5 \mathrm{~mm} \mathrm{Cu}$ collimator, developed due to specific sample geometrical and topography characteristics. Obtained results showed that implant alloys are not exactly $\mathrm{TiCP}$ but were manufactured using Ti-Al-V alloy, which contained $\mathrm{Fe}, \mathrm{Ni}, \mathrm{Cu}$ and $\mathrm{Zn}$. The presence of such metals as $\mathrm{Al}$ and $\mathrm{V}$ in all studied samples shows very clear that studied implants were not manufactured from TiCP alloy. Moreover, according to the American Society for Testing and Materials (ASTM), these elements should not be present in TiCP.
\end{abstract}

Keywords: Dental implants, XRF, Alloy metal.

ISSN: 2319-0612

Accepted: 2018-10-27 


\section{INTRODUCTION}

The dental implant is a prosthetic device used to fill the space without the tooth and reestablish the patient's masticatory function. It needs to have high biocompatibility, optimal integration to the tissues and good transmission of the functional forces to the bone [1]. Usually the dental implants are made of a Ti alloy with stabilizing elements such as $\mathrm{Al}, \mathrm{V}, \mathrm{Ni}, \mathrm{Fe}, \mathrm{Cu}, \mathrm{Co}$ and $\mathrm{Zn}$. These phase stabilizers have the function of imparting mechanical resistance to chewing forces and corrosion resistance [2, 3].

However, some of these elements can be toxic to the human body. Aluminium may be associated with Alzheimer's disease and its ions may cause desquamation of the respiratory tract mucosa and impair the production of blood cells due to exposure of body fluids for long periods [4]. Dental implants must present high biocompatibility to the living tissue. The same has to occur with the material interaction with peri-implant tissue and even tissues distant from the site of implantation because toxic reactions are likely to occur according to the metal and its oxidation rate [6].

This issue goes back to the classification of metallic alloys according to phase stabilizing elements such as Aluminum (Al), Vanadium (V), Nickel (Ni), Iron (Fe), Copper (Cu), Cobalt (Co), Zinc (Zn), among others [3]. In Brazil, the National Health Surveillance Agency (ANVISA), does not require any identification of the elements that may be part of the alloy composition and / or surface treatment of dental implants. The only requirement is to be classified as Class III (invasive, long term use, and don't produce harmful biological health effects) [7].

So, in the area of implantology, the issues of health risks are treated and studied according to the biocompatibility of implantable materials, as in the case of dental implant alloys. Clinical trials show that no implantable material has been completely free to cause adverse reactions in the human body $[5,8]$. In this sense, several studies related to clinical experiences regarding toxicity potential have reported that, most metals can affect multiple organic systems by oxidation (liberation of ions). Implantable engineering analysis includes the design optimization, considerations related to the model, the type of biomaterial used in manufacturing and restrictions on materials that can be safely used [6]. 
The American Society of Metals establish the reference limit of $98.635 \%$ to $99.5 \%$ of $\mathrm{Ti}$, for the metal alloy used in dental implants manufacturing to be considered as commercially pure (cpTi) titanium (ASM,1990) [12]. According to the American Society for Testing and Materials (ASTM), $\mathrm{Al}$ and $\mathrm{V}$ should not be present in cpTi and in agreement with the National Institute of Standards and Technology (NIST), the presence of $\mathrm{Al}$ should be lower than $0.01 \%$ and $\mathrm{V}$ should be of $0.009 \pm$ $0.001 \%[13-15]$.

The Energy Dispersive X-ray Fluorescence Spectroscopy (EDXRF) technique allows to analyze the elemental composition and quantifying samples from different matrices. This method gives a possibility to perform the qualitative and quantitative analysis of the materials using the spectra of the characteristic X-rays emitted by chemical elements present in the metal samples [9]. Thus, the present study sought to evaluate the type of implant materials available for the research and to correlate its elemental composition to the issues cited.

\section{MATERIALS AND METHODS}

For the characterization of the elements present in the samples of dental implants, two EDXRF equipment were used: one located at Laboratory of Applied Nuclear Physics of UTFPR and other at the Institute of Physics of the University State of Rio de Janeiro (UERJ). The samples used in this research were 13 dental implants already used and without model or brand registration (Figure 1).

Figure 1: Implant sample with photomicrography by MEV showing surface design 


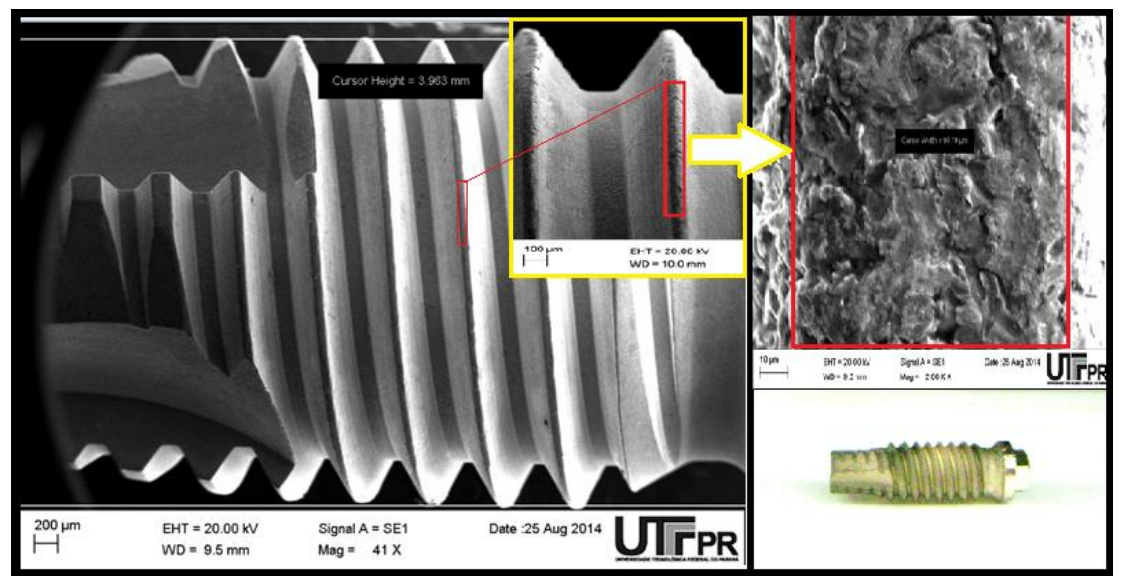

The EDXRF technique used in the UTFPR consists of experimenter kit with two X-ray tubes, gold $(\mathrm{Au})$ target and silver (Ag) target, and detectors SDD-123 model, both of brand Amptek (Figure 2).

Figure 2: Two models of Amptek experimenter kit equipped with X-ray tubes with Ag and Au targets

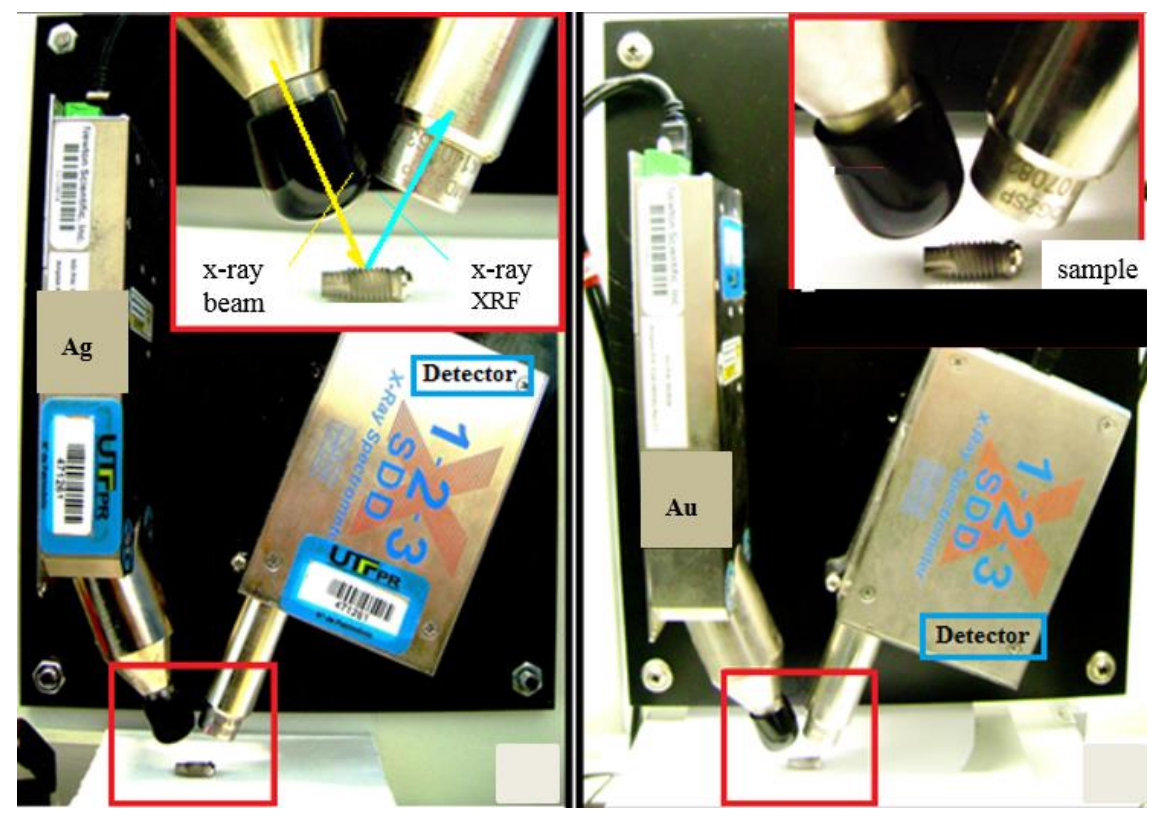

For the qualitative and quantitative analysis, the $\mathrm{Ag}$ tube and the Au tube were used. For the analysis, he samples were submitted to $30 \mathrm{kV}, 15 \mu \mathrm{A}$ e $900 \mathrm{~s}$ (Ag tube) and $40 \mathrm{kV}, 15 \mu \mathrm{A}$ e $900 \mathrm{~s}$ (Au 
tube) with $0.5 \mathrm{~mm}$ collimator and $1.0 \mathrm{~cm}$ distance between the tube-detector set and the sample. INAC 2017, Belo Horizonte, MG, Brazil. Geometrical form and surface design of dental implants made very difficult to perform the analysis of EDXRF spectra. To reduce the background of the measurements and to define better their geometry in the case of AMPTEK experimenter kit, three different collimators with internal diameters of $0.5 \mathrm{~mm}, 1 \mathrm{~mm}$ and $2 \mathrm{~mm}$ for output X-ray beam were used (Figure 3).

Figure 3: Collimators used with AMPTEK experimenter kit

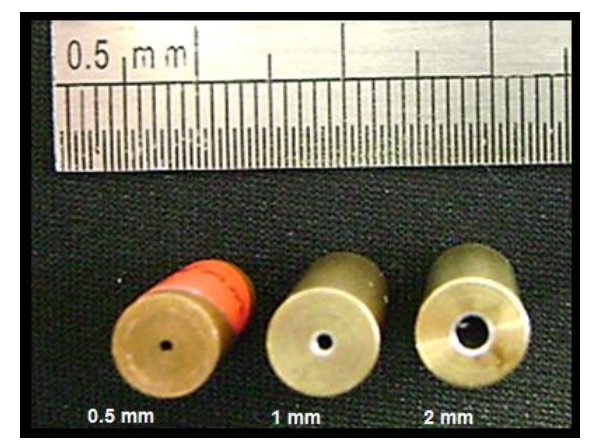

With the propose to confirm the presence of chemical elements found in studied samples with EDXRF analysis using X-Rat tube with the Au and Ag target other set of measurements were performed with the ARTAX 200 equipment at UERJ. The measurements were conducted using the ARTAX 200 (BRUKER) equipment with a molybdenum (Mo) target, SDD detector, $25 \mathrm{kV}, 300$ $\mu \mathrm{A}, 300 \mathrm{~s}$, collimator of $0.65 \mathrm{~mm}$ with $1.0 \mathrm{~cm}$ distance between the tube-detector set and the sample (Figure 4).

Figure 4: Schematic view of EDXRF measurements with ARTAX 200 equipment 


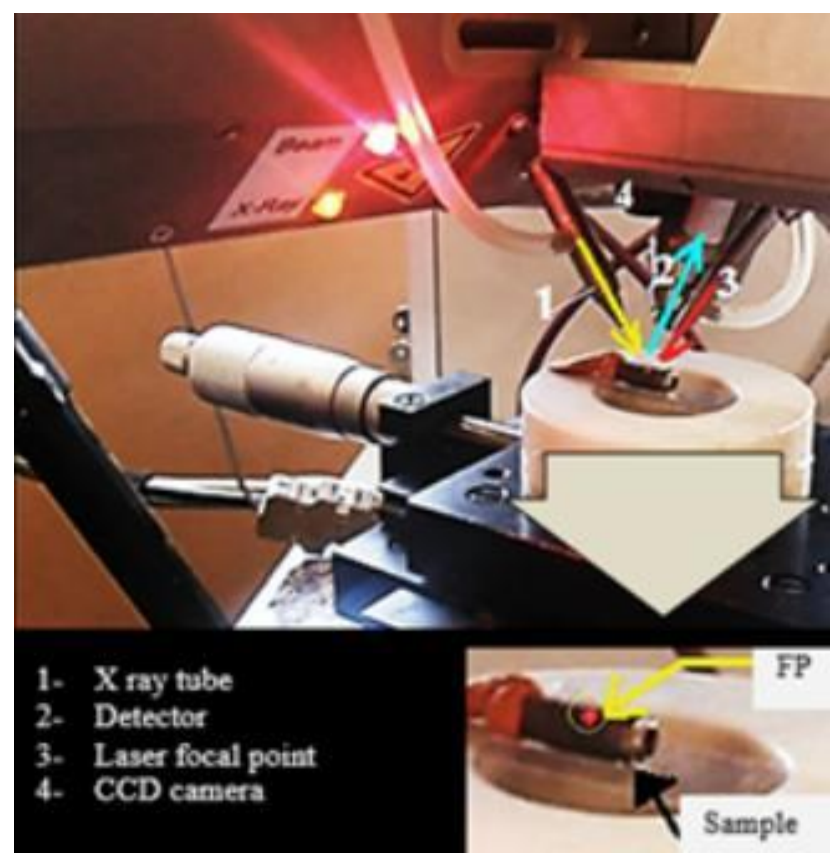

The quantitative analysis was carried considering the data presents in the National Institute of Standards and Technology (NIST) norms (ASTM F67-06 and ASTM F67-13) [10, 11, 13-15].

\section{RESULTS AND DISCUSSION}

The measurements with the different tubes of the Mini-X equipment showed better efficiency with the use of the Au target and $0.5 \mathrm{~mm}$ collimator (Figure 5). These results were confirmed by the Mo target (Figure 6). The dental implants elemental composition determined by EDXRF analysis shows Ti-Al-V alloy with addition of $\mathrm{Fe}, \mathrm{Ni}, \mathrm{Cu}$ e $\mathrm{Zn}$. The concentration of $\mathrm{Ti}$ in studied dental implants obtained by the elementary characterization varied between $93.35 \pm 0.17 \%$ and $95.34 \pm 0.19 \%$. These values are considered below the reference limit of $98.635 \%$ to $99.5 \%$ for cpTi alloy, established by Association of metals centric materials engineers and scientists Society (ASM). 
Figure 5: An example of spectra collected with X-Ray tubes equipped with Au and Ag targets and using $0.5 \mathrm{~mm}$ collimator

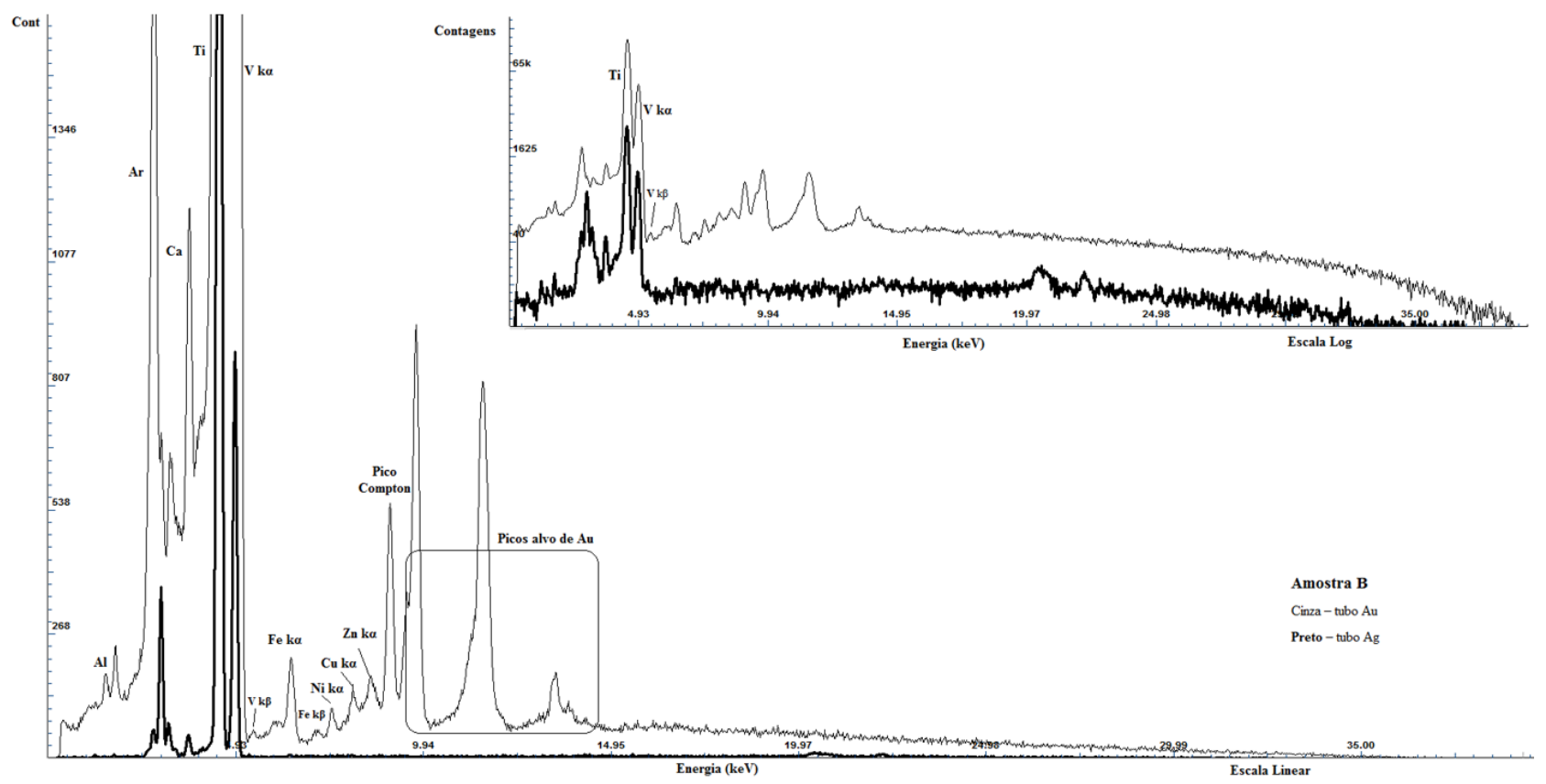

Figure 6: An example of spectrum collected with X-Ray tubes equipped with from Mo target 


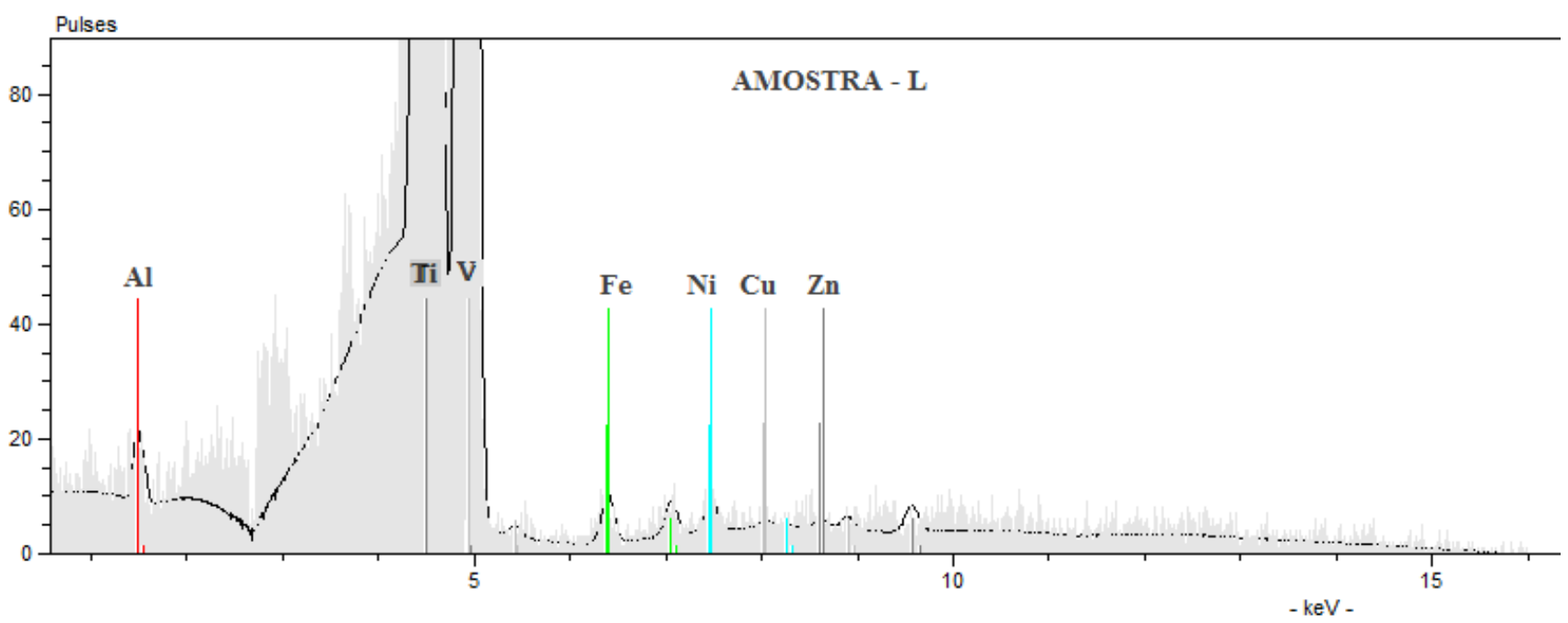

The presence of elements $\mathrm{Al}$ and $\mathrm{V}$ in all samples also supports the conclusion that studied dental implants were not manufactured from cpTi alloys. The concentration values of $\mathrm{Al}$ in all studied samples vary between $6.3 \pm 1.3 \%$ and $3.7 \pm 2.0 \%$ and for $\mathrm{V}$, between $0.26 \pm 0.09 \%$ and $0.112 \pm$ $0.048 \%$. According to the American Society for Testing and Materials (ASTM), these elements should not be present in cpTi and in accordance with the National Institute of Standards and Technology (NIST), the presence of $\mathrm{Al}$ should be lower than $0.01 \%$ and $\mathrm{V}$ should not exceed $0.009 \pm$ $0.001 \%$.

\section{CONCLUSION}

The quantitative analysis of obtained experimental results and elementary characterization of the dental implants show that the best accuracy and precision were reached with X-Ray tube with $\mathrm{Au}$ target and collimator of $0.5 \mathrm{~mm}$. Performed analysis of experimental data shows that the dental implant materials cannot be categorized as cpTi alloys and very probably they were manufactured using Ti-Al-V alloy, which contained trace elements such as $\mathrm{Fe}, \mathrm{Ni}, \mathrm{Cu}$ and $\mathrm{Zn}$. However, diverse biological responses to these materials depend on whether they release their components and whether those components are toxic, for example, the Al may be associated with Alzheimer's disease. In this regard, it is important to conclude that the biocompatibility of medical implant materi- 
als requires further continues studies in order to minimize risks for patients as well as to improve their performance.

\section{ACKNOWLEDGMENT}

The authors are very thankful to Coordenação de Aperfeiçoamento de Pessoal de Nível Superior (CAPES) and the Graduate Course in Electrical Engineering and Industrial Informatics (CPGEI, UTFPR) for financial support as well as to colleagues from the State University of Rio de Janeiro (UERJ) for the research support.

\section{REFERENCES}

1. HADDAD, M.F.; PELlIZZER, E.P.; MAZARO, J.V.Q.; VERRI, F.R.; FALCÓNANTENUCCI, R.M. Conceitos básicos para a reabilitação oral por meio de implantes osseointegrados - parte I: influência do diâmetro e do comprimento. Revista Odontológica de Araçatuba, v.290, n.1, pp. 30-37, 2008.

2. AOKI, T.; OKAFOR, I.C.I.; WATANABE, I.; HATTORI, M.; ODA, Y.; OKABE, T. Mechanical properties of cast Ti-6Al-4V-XCu alloys. Journal of Oral Rehabilitation, v. 31, n.11, pp.1109-1114, 2004.

3. LEYENS, C.; PETERS, M. Titanium and titanium alloys: fundamentals and applications, Weinheim, WILEY-VCH Verlag GmbH \& Co. KGaA, 2003.

4. LIU, P.; YAO,Y.N.; WU, S.D.; DONGA, H-J.; FENGA, G-C.; YUANA, X-Y. The efficacy of deferiprone on tissues aluminumremoval and copper, zinc, manganese level in rabbits. $\mathbf{J}$. Inorg Biochem, v. 99, n.8, pp. 1733-1737, 2005.

5. WATAHA, J. C. Biocompatibility of dental casting alloys: a review. J Prosthet Dent, v.83, n.2, pp. 223-234, 2000. 
6. PALMQUIST, A.; OMAR, M.O.; ESPOSITO, M.; LAUSMA, A. J.; THOMSEN, P. Titanium oral implants: surface characteristics, interface biology and clinical outcome. J. R. Soc. Interface, v.7, pp.515-527, 2010.

7. ANVISA - Agencia Nacional de Vigilância Sanitária. Manual do usuário da resoluçãoRDC n' 185/2001: orientações sobre registro, cadastramento, alterações, revalidações e cancelamento do registro de produtos médicos. Brasília, DF, Brazil, 2001. Available at: <http://200.189.113.52/ftp/Visa/correlatos/ManualdoUsuariodaRDC185.pdf>. Lasted acessed: Jun. 2014.

8. MISCH, C. E. Implante Odontológico Contemporâneo, $3^{\mathrm{a}}$ ed. Rio de Janeiro: Elsevier, 2009.

9. GRIEKEN, R. E. V.; MARCOWICZ, A. A. Handbook of X-Ray Spectrometry, $2^{\text {rd }}$ ed. New York: Marcel Dekker, 2002.

10. ASTM - American Society for Testing and Materials. Designation F67-06: Standard Specification for Unalloyed Titanium, for Surgical Implant Applications. ASTM Report UNS R50250, UNS R50400, UNS R50550, UNS R50700, West Conshohocken: ASTM, 2006.

11. ASTM - American Society for Testing and Materials. Designation F67-13: Standard Specification for Unalloyed Titanium, for Surgical Implant Applications. Report UNSR50250, UNS R50400, UNS R50550, UNS R50700, West Conshohocken: ASTM, 2013.

12. ASM Handbook, Properties and Selection: Nonferrous Alloys and Special-Purpose Materials, v.2, $10^{\text {rd }}$ ed. United States of America: ASM International Handbook Committee, 1990.

13. NIST - National Institute of Standards and Technology. unalloyed titanium A. Report SRM 650, Gaithersburg: NIST,1985.

14. NIST - National Institute of Standards and Technology. titanium Alloy 6Al-4V. Report SRM 654b, Gaithersburg: NIST, 2013.

15. NIST - National Institute of Standards and Technology. Ti-Al-V SRM 173c. Report SRM 173c, Gaithersburg: NIST, 2016. 